\title{
Isolasi dan Uji Aktivitas Antioksidan Ekstrak Metanol Buah Senduduk Bulu (Clidemia hirta (L.) D. Don)
}

\section{Isolation and Antioxidant Activity of Methanol Extract of Senduduk Bulu (Clidemia hirta (L.) D. Don) Fruit}

\author{
Haiyul Fadhli*, Ihsan Ikhtiarudin, Putri Lestari \\ Sekolah Tinggi Ilmu Farmasi Riau, Jalan Kamboaja, Simpang Baru, Tampan, Simpang Baru, Kec. \\ Tampan, Kota Pekanbaru, Riau 28289, Indonesia \\ *E-mail: haiyulfadhli@stifar-riau.ac.id
}

Received: 10 Januari 2020; Accepted: 14 Desember 2020; Published: 31 Desember 2020

\begin{abstract}
Abstrak
Telah dilakukan penelitian tentang isolasi dan uji aktivitas antioksidan senyawa metabolit sekunder dari ekstrak metanol buah senduduk bulu (Clidemia hirta (L.) D. Don). Secara tradisional Senduduk bulu telah digunakan sebagai obat-obatan untuk menyembuhkan berbagai penyakit. Tumbuhan ini mengandung senyawa flavonoid, fenolik dan terpenoid. Senyawa flavonoid dan fenolik dilaporkan mempunyai aktivitas sebagai antioksidan. Tujuan penelitian ini untuk mengisolasi kandungan kimia dan menguji aktivitas antioksidan dari buah Senduduk bulu. Isolasi dilakukan dengan menggunakan metode Kromatografi Cair Vakum dan kromatografi kolom. Aktivitas antioksidan dilakukan dengan metode metode DPPH. Hasil isolasi menghasilkan $10 \mathrm{mg}$ senyawa isolat CHP1 berbentuk kristal putih, dengan titik leleh $165-167^{\circ} \mathrm{C}$, larut dalam kloroform dan agak sukar larut dalam metanol. Senyawa ini memberikan reaksi positif dengan pereaksi Liebermann-Burchard (LB), sehingga disimpulkan senyawa ini merupakan golongan terpenoid. Hasil spektrum UV, menunjukkan $\lambda$ maks senyawa tersebut adalah $316 \mathrm{~nm}$. Spektrum FT-IR menunjukkan adanya beberapa gugus fungsi $\mathrm{OH}, \mathrm{C}-\mathrm{H}$ alifatis, $\mathrm{C}=\mathrm{O}$ ester, $\mathrm{C}=\mathrm{C}$ alkena, $\mathrm{CH}$ bending dan $\mathrm{C}-\mathrm{O}$. Spektrum ${ }^{1} \mathrm{H}$ NMR menunjukkan adanya proton alkena dan gugus proton metil yang merupakan ciri khas senyawa terpenoid. Senyawa murni (CHP1) memberikan aktivitas antioksidan yang lemah dengan $\mathrm{IC}_{50}$ sebesar $327,01 \mu \mathrm{g} / \mathrm{mL}$.
\end{abstract}

Kata kunci : Antioksidan, Buah Senduduk Bulu (Clidemia hirta (L.) D. Don), DPPH, Isolasi

\begin{abstract}
A study on isolation and antioxidant activity of secondary metabolit of methanol extract of fruit of Senduduk Bulu (Clidemia hirta (L.) D. Don) has been carried out. Senduduk bulu is used for folk medicine to many diseases. Flavonoid and phenolic has been reported to its activity as antioxidant. The aim of this research was to find antioxidant compound and antioxidant activity of this fruit. Isolation works were conducted using Vacuum Liquid Chromatography and Column Chromatography method. Antioxidant activity was determined using DPPH free radical scavenging methods. The isolation works afforded 10 mg of pure compound CHPI which was obtained as white crystal, with its melting point of $165-167^{\circ} \mathrm{C}$, soluble in chloroform and slightly soluble in methanol. This compound gave positive reaction with Liebermann-Burchard (LB) reagent and concluded as terpenoid. Based on it UV spectrum, this compound showed a $\lambda$ max of $316 \mathrm{~nm}$. Its FT-IR spectrum showed appearence of some functional groups of OH, $\mathrm{C}-\mathrm{H}$ aliphatic, $C=O$ ester, $C=C$ alkene, $C H$ bending and $C-O$. The ${ }^{1} H$-NMR spectrum showed the alkene protons and methyl protons which is a characteristic of terpenoid compounds. The pure compound (CHP1) provided a weak antioxidant activity with the $I C_{50}$ of $327,01 \mu \mathrm{g} / \mathrm{mL}$.
\end{abstract}

Keywords: Antioxidant, DPPH, Isolation, Senduduk Bulu (Clidemia hirta (L.) D. Don) fruit

\section{PENDAHULUAN}

Setiap tumbuhan memiliki beragam kandungan senyawa kimia serta memiliki khasiat dan manfaat. Upaya pencarian tumbuhan berkhasiat obat telah lama dilakukan, baik untuk mencari senyawa baru ataupun menambah keanekaragaman senyawa yang telah ada. Pencarian tersebut dilakukan 
dengan berbagai pendekatan seperti cara empiris, etnobotani dan etnofarmakologi (Djauhariya,2004).

Salah satu spesies tumbuhan yang dapat digunakan dalam pengobatan dan memiliki aktivitas sebagai antioksidan adalah tumbuhan dari famili Melastomataceae. Tumbuhan dengan famili Melastomataceae sebagian besar merupakan tumbuhan pantropis yang terdiri dari 163 marga dan 4300 spesies. Famili Melastomataceae dilaporkan merupakan tanaman yang kaya akan senyawa fenolik dan flavonoid. Kandungan fitokimia dari tumbuhan Melastomataceae diantaranya adalah senyawa fenolik, flavonoid, tannin, terpenoid, saponin, steroid, glikosida, dan alkaloid. Diketahui beberapa spesies dari famili ini memiliki beberapa aktivitas seperti antioksidan, antihipertensi, antihiperglikemik, homeo-statis, antihepatitis dan antidiare (Tjitraresmi et al., 2018).

Beberapa spesies Melastomataceae yang diketahui mengandung senyawa fenolik yang cukup besar yaitu Melastoma malabathricum sebesar 384,33 mg AG/g, pada Meriania hernandoi sebesar $240 \mathrm{mg} \mathrm{AG/g} \mathrm{dan} \mathrm{pada}$ Miconia albicans sebesar 70,04 mg AG/g. Selain itu ekstrak metanol daun Melastoma malabathricum berpotensi sebagai antikanker payudara pada sel kanker MCF-7 dengan nilai $\mathrm{IC}_{50}$ sebesar $7,14 \mu \mathrm{g} / \mathrm{mL}$ dan ekstrak etanol daun Clidemia hirta berpotensi sebagai antiproliferasi terhadap sel kanker Dalton's Lymphoma Ascites (DLA) dengan nilai $\mathrm{IC}_{50}$ sebesar $68 \mu \mathrm{g} / \mathrm{mL}$ (Tjitraresmi et al., 2018).

Beberapa penelitian terkait Senduduk Bulu (Clidemia hirta (L.) D. Don) telah dilakukan. Perdede (2018) dalam penelitiannya menyatakan bahwa hasil pengujian aktivitas antioksidan dari ekstrak etanol buah senduduk bulu dengan metode DPPH memiliki nilai $\mathrm{IC}_{50}$ sebesar 12,568 $\mu \mathrm{g} / \mathrm{mL}$. Hasil Penelitian Narasimham et al (2017), menunjukkan bahwa ekstrak etanol daun Senduduk bulu memiliki aktivitas antioksidan dengan metode DPPH nilai $\mathrm{IC}_{50}$ sebesar $5 \mu \mathrm{g} / \mathrm{mL}$. Pada penelitian tersebut digunakan kontrol positif asam askorbat yang memiliki nilai $\mathrm{IC}_{50}$ sebesar $3,7 \mu \mathrm{g} / \mathrm{mL}$.

Berdasarkan uraian diatas, maka dilakukan penelitian tentang isolasi senyawa metabolit sekunder yang terkandung dalam buah senduduk Bulu (Clidemia hirta (L.) D.Don) serta menguji aktivitasnya antioksidannya. Isolasi metabolit sekunder buah senduduk bulu menggunakan VLC (Vacuum Liquid Chromatography) dan kromatografi kolom, sedangkan uji aktivitas antioksidan, dilakukan dengan menggunakan metode DPPH, sedangkan penelitian ini diharapkan dapat memberikan informasi tentang kandungan metabolit sekunder dari ekstrak total metanol buah Senduduk Bulu (Clidemiahirta (L.) D. Don) serta dapat digunakan sebagai panduan tambahan sumber alami tumbuhan yang berpotensi sebagai antioksidan.

\section{METODE PENELITIAN Alat Penelitian}

Alat yang digunakan dalam penelitian ini adalah seperangkat alat destilasi $\left(\mathrm{Gopal}^{\circledR}\right)$, satu unit rotary evaporator $\left(\right.$ Buchi $\left.^{\circledR}\right)$, neraca analitik, seperangkat alat Vacuum Liquid Chromatography (VLC), kolom kromatografi $\left(\right.$ Pyrex $\left.^{\circledR}\right)$, plat KLT GF $254\left(\right.$ Merck $\left.^{\circledR}\right)$, lampu UV 254 dan $366 \mathrm{~nm}$ (Camag, $\left.{ }^{\circledR}\right)$ melting point apparatus (SMP11), spektrofotometer UVVis (Shimadzu ${ }^{\circledR}$ UV-1800), spektrofotometer FT-IR $\quad\left(\right.$ Shimadzu ${ }^{\circledR}$ IR Prestige-21), Spektroskopi NMR (Agilent, $500 \mathrm{MHz}$ ), microplate reader (Tristar LB 941 Berthold $^{\circledR}$ ) dan pipet mikro $\left(\mathrm{Nesco}^{\circledR}\right)$ dan peralatan gelas yang umum digunakan (Pyrex ${ }^{\circledR}$ )

\section{Bahan Penelitian}

Bahan yang digunakan adalah pelarut organik kualitas teknis dan telah didestilasi (n-heksana, etil asetat, metanol), silika gel 60 (70-230 mesh), kloroform, kloroform amoniak $0,05 \mathrm{~N}$, asam sulfat $2 \mathrm{~N}$, pereaksi Meyer, logam magnesium, asam klorida pekat, besi (III) klorida 1\%, asam asetat anhidrat, asam sulfat pekat, norit, reagen (1,1difenil-2-pikrilhidrazil (DPPH) (Sigmaaldrich ${ }^{\circledR}$ ) dan asam askorbat $\left(\right.$ Merck $\left.^{\circledR}\right)$ 


\section{Pengambilan Sampel Tumbuhan}

Sampel yang digunakan untuk penelitian ini adalah buah senduduk bulu (Clidemia hirta (L.) D. Don). sebanyak 4,5 kg yang diambil dari Kecamatan Kandis, Kabupaten Siak.

\section{Identifikasi Tumbuhan Senduduk Bulu}

Identifikasi tumbuhan senduduk bulu dilakukan di Laboratorium Botani Jurusan Biologi Fakultas Matematika dan Ilmu Pengetahuan Alam (FMIPA) Universitas Riau, Pekanbaru.

\section{Pembuatan Ekstrak Metanol Buah Senduduk Bulu}

Ekstraksi dilakukan dengan metode maserasi, serbuk kering buah senduduk bulu (Clidemia hirta (L.) D.Don) sebanyak 950 gram direndam dalam wadah yang tertutup baik dan terlindung dari cahaya denganpelarut metanol selama 5 hari pada suhu kamar sambil diaduk satu kali sehari, lalu disaring. Proses ekstraksi ini dilakukan sebanyak 3 kali pengulangan sampai diperoleh filtrat yang cukup bening. Maserat yang didapat diuapkan dari pelarutnya dan dipekatkan dengan menggunakan alat rotary evaporator sehingga didapatkan ekstrak kental metanol sebanyak 112,057 gram.

\section{Skrining Fitokimia Ekstrak}

Pemeriksaan fitokimia yang dilakukan meliputi pemeriksaan alkaloid, terpenoid, steroid, flavonoid, fenolik dan saponin.

Fraksinasi ekstrak dengan Vacuum Liquid Chromatography (VLC)

Untuk memisahkan senyawa-senyawa yang ada di dalam ekstrak dilakukan pemisahan dengan VLC. Sebanyak 25 gram ekstrak dimasukkan pada kolom VLC lalu dielusi dengan campuran beberapa eluen $n$ heksana dengan etil asetat dan etil asetat dengan metanol yang dibuat dalam 17 macam perbandingan eluen, yaitu $n$-heksana $100 \%$, $n$-heksana:etil asetat $(9: 1),(8: 2),(7: 3),(6: 4)$, (5:5), (4:6), (3:7), (2:8), (1:9), etil asetat $100 \%$, etil asetat:metanol $(9: 1),(8: 2),(7: 3)$, (6:4), (5:5) dan (4:6)

Uji Pendahuluan Aktivitas Antioksidan Terhadap Fraksi Hasil VLC
Uji pendahuluan aktivitas antioksidan terhadap fraksi hasil VLC dilakukan dengan menyemprot KLT fraksi dengan larutan DPPH $0,2 \%$ dalam metanol. Kromatogram diperiksa 30 menit setelah penyemprotan (Demirezer et al. 2001). Senyawa aktif penangkap radikal bebas akan menunjukkan bercak berwarna kuning pucat dengan latar belakang ungu. Fraksi yang aktif (F12) kemudian dilanjutkan uji aktivitas antioksidan dengan menggunakan microplate reader.

\section{Isolasi dengan Metode Kromatografi Kolom}

Untuk memisahkan senyawa-senyawa yang ada di dalam fraksi (F12) hasil VLC tersebut, selanjutnya dilakukan pemisahan dengan metode kromatografi kolom dengan fase diam silika gel 60 (70-230 mesh). Kemudian dielusi secara bergradien menggunakan pelarut $n$-heksana $100 \%$, kombinasi campuran pelarut $n$-heksana : etil asetat (9:1), perbandingan etil asetat: metanol, sampai metanol $100 \%$. Hasil pemisahan ditampung dalam wadah vial dan diperoleh hasil pemisahan kromatografi kolomsebanyak 135 vial. Hasil pemisahan menunjukan adanya pola noda yang baik pada vial 41-51 dan terdapat kristal yang warnanya lebih homogen dibandingkan kristal pada vial lainnya. vial 41-51 ini digabung (CHP1) dan dicuci (washing) dan rekristalisasi. Selanjutnya kristal CHP1 yang didapat dimonitor kembali pada plat KLT di bawah lampu UV $254 \mathrm{~nm}$ dan $366 \mathrm{~nm}$ untuk melihat kemurnian dari senyawa tersebut dan menunjukkan satu noda tanpa adanya noda lain yang mengganggu.

\section{Identifikasi Senyawa Isolat}

Senyawa CHP1, diidentifikasi lebih lanjut meliputi pemeriksaan organoleptis, sifat fisika dan sifat kimia serta analisis senyawa secara spektroskopi menggunakan spektrofotometer UV-Vis, spektrofotometer FT-IR (Lab. Kimia Fisika FMIPA UR) dan spektroskopi H-NMR (Lab. Kimia FMIPA ITB).

\section{Pengujian Aktivitas Antioksidan}


a. Persiapan Larutan Uji Fraksi F12 dan senyawa CHP1

Fraksi 12 dan senyawa isolat CHP1 masingmasing ditimbang sebanyak $10 \mathrm{mg}$ dan dilarutkan dalam $10 \mathrm{~mL}$ metanol sehingga didapatkan larutan induk dengan konsentrasi $1000 \mu \mathrm{g} / \mathrm{mL}$.

b. Pembuatan Larutan Vitamin C

Vitamin $\mathrm{C}$ sebagai antioksidan pembanding ditimbang sebanyak $10 \mathrm{mg}$ dan dilarutkan dalam $10 \mathrm{~mL}$ metanol sehingga didapatkan konsentrasi larutan induk $1000 \mu \mathrm{g} / \mathrm{mL}$ kemudian diencerkan menjadi $100 \mu \mathrm{g} / \mathrm{mL}$.

c. Pembuatan Larutan DPPH

Sebanyak $10 \mathrm{mg}$ DPPH ditimbang dan dilarutkan dalam $10 \mathrm{~mL}$ larutan metanol lalu disimpan di dalam vial gelap sehingga didapatkan larutan DPPH dengan konsentrasi $1000 \mu \mathrm{g} / \mathrm{mL}$. Larutan tersebut kemudian diencerkan menjadi $80 \mu \mathrm{g} / \mathrm{mL}$.

d. Pengujian Aktivitas Antioksidan dengan Metode DPPH

Uji aktivitas antioksidan dilakukan dengan metode DPPH menggunakan microplate reader mengikuti metode yang telah dilakukan Kedare dan Singh (2011) yang telah dimodifikasi (Fadhli, et. al., 2019). Microplate yang digunakan terdiri dari baris A-H dan masing-masing baris memiliki 12 sumur. Masin-masing larutan induk sampel) Pada baris A dimasukan masing-masing larutan sampel (F12 dan senyawa CHP1) sebanyak $100 \mu \mathrm{L}$. Tambahkan metanol $50 \mu \mathrm{L}$ pada masing-masing baris B-H. Baris A dipipet sebanyak $50 \mu \mathrm{L}$ lalu dimasukan ke baris $\mathrm{B}$, dari baris $\mathrm{B}$ dipipet $50 \mu \mathrm{L}$ dan dimasukan ke baris $C$, dan begitu seterusnya sampai pada baris F. pada baris $\mathrm{F}$ dipipet 50 $\mu \mathrm{L}$ dan dibuang. Maka dengan demikian diperoleh konsentrasi A-F secara urut adalah $1000 ; 500 ; 250 ; 125 ; 62,5$ dan $31,25 \mu \mathrm{g} / \mathrm{mL}$. Baris $\mathrm{G}$ dan $\mathrm{H}$ diisi dengan pelarut metanol 50 $\mu \mathrm{L}$, kemudian baris A-G ditambahkan DPPH konsentrasi $80 \mu \mathrm{g} / \mathrm{mL}$ sebanyak $80 \mu \mathrm{L}$. Lalu larutan uji dibiarkan selama 30 menit pada suhu ruangan dan terhindar dari cahaya. Selanjutnya, absorbansi larutan uji diukur pada panjang gelombang $517 \mathrm{~nm}$ dengan microplate reader. Aktivitas penangkapan radikal bebas ditandai dengan terjadinya penurunan absorbansi. Kontrol positif yang digunakan sebagai antioksidan pembanding adalah asam askorbat dengan konsentrasi 100; $50 ; 25 ; 12,5 ; 6,25$ dan $3,125 \mu \mathrm{g} / \mathrm{mL}$.

\section{Analisis data}

Persentase inhibisi terhadap radikal bebas DPPH dapat dihitung dengan menggunakan persamaan 1 .

$\%$ Inhibisi $=\underline{\text { Abs DPPH }- \text { Abs sampel }} \times 100 \%$......(1) Abs DPPH

Untuk menentukan nilai $\mathrm{IC}_{50}$ dari masing-masing sampel diplot masing-masing konsentrasi sampel dan persen inhibisinya pada sumbu $\mathrm{x}$ dan y pada persamaan regresi linear.

\section{HASIL DAN PEMBAHASAN}

Sebanyak 2,5 kg simplisia buah senduduk bulu (Clidemia hirta (L.) D. Don) diekstraksi dengan metode maserasi menggunakan pelarut metanol. Hasil ekstrak metanol buah senduduk bulu dilakukan pemeriksaan kandungan metabolit sekunder. Buah senduduk bulu positif mengandung senyawa golongan flavonoid, fenolik dan terpenoid. Hasil positif flavonoid ditandai dengan terbentuknya warna merah muda setelah ditambahkan $\mathrm{HCl}$ pekat dan logam Mg. Pembentukan warna merah muda tersebut disebabkan oleh tereduksinya inti benzopiron yang terdapat dalam struktur flavonoid sehingga terbentuk garam flavilium berwarna yang merah, lembayung merah atau jingga (Ergina dan Indarini, 2014).

Adanya kandungan senyawa terpenoid pada sampel segar ditandai dengan timbulnya warna merah setelah penambahan asam asetat anhidrat dan asam sulfat pekat, warna tersebut dihasilkan oleh hasil reaksi antara pereaksi dengan senyawa terpenoid yang terdapat di dalam sampel (Agustina et al., 2017). Sedangkan adanya senyawa golongan fenolik ditandai dengan terbentuknya warna hijau kehitaman. Penambahan reagen $\mathrm{FeCl}_{3}$ akan 
bereaksi dengan gugus hidroksil yang terdapat pada senyawa fenolik dan akan menghasilkan senyawa kompleks yang berwarna hijau atau biru kehitaman (Wijaya et al.,2015).

Selanjutnya ekstrak metanol buah senduduk bulu yang telah diuji dengan metode KLT, dilakukan pemisahan dengan metode VLC. VLC merupakan salah satu metode fase diam yang digunakan berupa silika gel 60 (230-400 mesh) dengan fase gerak sistem gradien yang kepolarannya ditingkatkan dimulai dari pelarut $n$-heksana, etil asetat dan metanol. Urutan eluen yang digunakan dalam kromatografi vakum diawali mulai dari eluen yang mempunyai tingkat kepolaran rendah kemudian kepolarannya ditingkatkan secara perlahan-lahan (Hostettmann et al.,1995).

Berdasarkan hasil VLC didapatkan 17 fraksi. Fraksi ke-17 merupakan fraksi etil asetat : metanol (40:60). Pemisahan dengan VLC ini terhenti pada fraksi 17 disebabkan silika yang terlalu padat sehingga vakum tidak mampu untuk memompa lagi. Kemudian fraksi 17 tersebut dengan rotary evaporator dan dikumpulkan dalam 17 vial yang diberi label F1 sampai dengan F17. Masing-masing fraksi F1-F17 tersebut diuji KLT dengan menggunakan eluen $n$-heksana : etil asetat (5:5) dan etil asetat : metanol (8:2) untuk mendapatkan profil KLT dari masingmasing fraksi. Berdasarkan hasil KLT, F12 menunjukkan pola noda yang lebih sederhana dibandingkan dengan fraksi lainnya.

Selanjutnya dilakukan uji pendahuluan aktivitas antioksidan menggunakan KLT dari fraksi hasil VLC. Uji pendahuluan antioksidan ini dilakukan untuk mengetahui ada atau tidaknya aktivitas antoksidan dari ekstrak metanol buah senduduk bulu. Kromatogram disemprot dengan pereaksi spesifik yaitu larutan 1,1- diphenyl-2picrylhydrazyl (DPPH) 0,2\% dalam metanol. Bercak yang dapat menangkap radikal bebas akan menghasilkan warna kuning dalam waktu tidak lebih dari 30 menit terindikasi sebagai antioksidan (Chowdhury et al., 2015). Pada pengujian ini ekstrak metanol simplisia buah senduduk bulu memberikan hasil positif pada fraksi F1-F17, yang ditandai dengan adanya noda kuning. Hasil pengujian tersebut menunjukkan bahwa sampel mampu meredam radikal bebas DPPH atau memiliki aktivitasantioksidan.

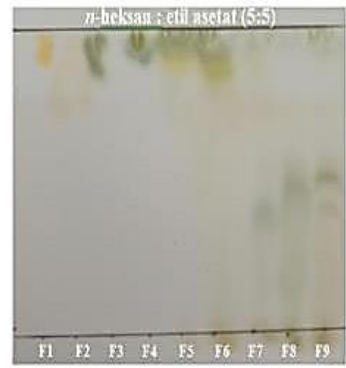

(a)

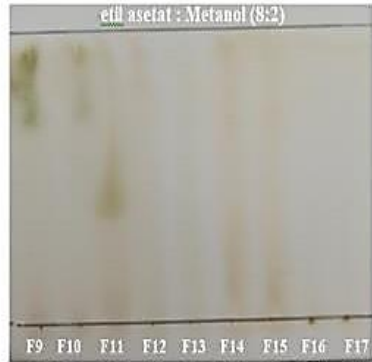

(b)
Gambar 1. Profil Komatografi Lapis Tipis Hasil Uji Pendahuluan Aktivitas Antioksidan Ekstrak Metanol Buah Senduduk Bulu

Sebanyak 0,218 gram F12 dimurnikan menggunakan kromatografi kolom diameter 1 $\mathrm{cm}$ menggunakan silika gel 60 (70-230mesh). Setelah itu pengelusian dilakukan dengan menggunakan pelarut berdasarkan metode SGP (Step Gradient Polarity). Setelah dilakukan pengelusian, hasil elusi ditampung didalam vial dan didapatkan sebanyak 135 vial, lalu di uji KLT dan uji pendahuluan antioksidan.

Setelah dilakukan uji pendahuluan aktivitas antioksidan, selanjutnya dilakukan pemurnian terhadap fraksi yang potensial sebagai antioksidan. Sehingga dipilihlah F12. Hasil pemisahan fraksi 12 dengan kromatografi kolom menunjukan adanya pola noda yang baik pada vial 41-vial 51 dan terdapat kristal yang warnanya lebih homogen dibandingkan kristal pada vial lainnya. Kristal yang diperoleh pada vial 41-51 ini dimurnikan dengan cara washing (pencucian) dan rekristalisasi. Pemurnian ini dilakukan berulang hingga didapat senyawa berbentuk kristal. Selanjutnya kristal yang didapat dimonitor kembali pada plat KLT di bawah lampu UV $254 \mathrm{~nm}$ dan $366 \mathrm{~nm}$ untuk melihat kemurnian dari senyawa tersebut, yang akan menunjukkan satu noda tanpa adanya noda lain yang mengganggu. Berdasarkan hasil 


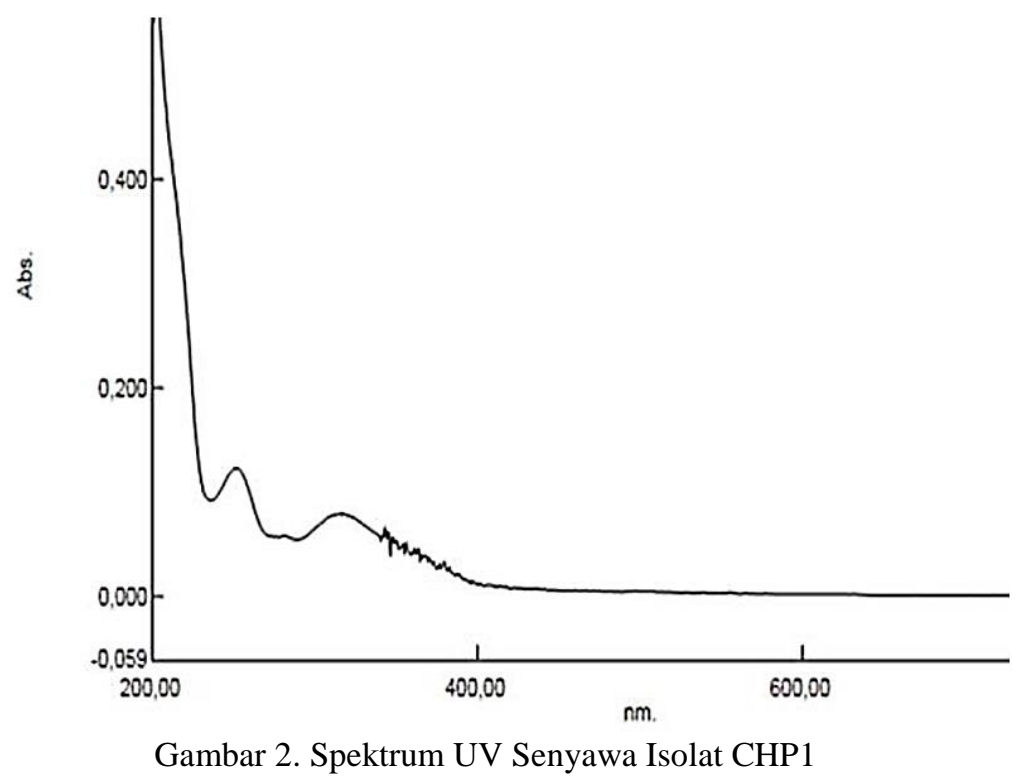

profil KLT senyawa CHP1 dengan tiga eluen berbeda yaitu etil asetat : metanol $(8: 2), n$ heksana : etil asetat (5:5) dan $n$-heksana : etil asetat $(7: 3)$ diperoleh nilai $\mathrm{R} f$ berturut-turut yaitu 0,$8 ; 0,4$ dan 0,1 .

Senyawa murni yang didapat sebanyak $10 \mathrm{mg}$ dan diberi label CHP1 dan dilanjutkan identifikasi senyawa secara organoleptis, pemeriksaan kimia, pemeriksaan fisika dan analisis spektroskopi UV-Vis, FT-IR dan NMR serta uji aktivitas antioksidan.

Pemeriksaan organoleptis diketahui bahwa senyawa murni CHP1 yang didapat berbentuk kristal, berwarna putih, larut dalam kloroform dan agak sukar larut dalam metanol. Pengukuran titik leleh senyawa murni CHP1 menggunakan Stuart Melting Point Apparatus (SMP-11) diperoleh titik leleh $165-167^{\circ} \mathrm{C}$. Jarak titik leleh dari senyawa murni CHP1 tidak lebih dari $2^{\circ} \mathrm{C}$ ini menunjukan bahwa senyawa yang sudah didapat telah murni. Senyawa murni CHP1 dilakukan pengujian penampak noda dengan menggunakan pereaksi Liebermann-Burchard dan terbentuk warna merah yang mengindikasikan senyawa golongan terpenoid.

Hasil yang diperoleh setelah dilakukan identifikasi dengan spektrofotometer UV terhadap senyawa CHP1 pada panjang gelombang 200-400 nm, hasil pengukuran menunjukan adanya gugus kromofor (Gambar 2). Kromofor adalah molekul atau bagian molekul yang mengabsorbsi sinar dengan kuat di daerah UV-Vis (Suhartati, 2017). Dari hasil pengukuran spektrofotometer UV, senyawa murni CHP1 menunjukkan tiga nilai serapan yaitu 0,080 pada panjang gelombang $316 \mathrm{~nm}$. Nilai absorbansi UV-Vis senyawa CHP1 dengan konsentrasi senyawa CHP1 menunjukkan hubungan yang tidak linear yang disebabkan konsentrasi senyawa CHP1 terlalu kecil.

Hasil identifikasi spektrofotometer FTIR (Gambar 3) diperoleh hasil bahwa senyawa isolat CHP1 mempunyai gugus fungsi $\mathrm{OH}$ pada daerah bilangan gelombang $3360 \mathrm{~cm}^{-1}$. Adanya bilangan gelombang pada daerah $2956 \mathrm{~cm}^{-1}, 2929 \mathrm{~cm}^{-1}$ dan $2852 \mathrm{~cm}^{-1}$ menunjukkan adanya gugus fungsi $\mathrm{C}-\mathrm{H}$ alifatis. Adanya bilangan gelombang pada daerah 1745 dan $1651 \mathrm{~cm}^{-1}$ menunjukkan adanya gugus fungsi $\mathrm{C}=\mathrm{O}$ ester dan serapan pada bilangan gelombang pada $1651,14 \mathrm{~cm}^{-1}$ menunjukkan adanya ikatan $\mathrm{C}=\mathrm{C}$ alkena. Adanya bilangan gelombang pada daerah $1458 \mathrm{~cm}^{-1}$ dan $1380 \mathrm{~cm}^{-1}$ menunjukkan adanya gugus fungsi $\mathrm{CH}$ Bending $(\mathrm{CH} 2$ dan 


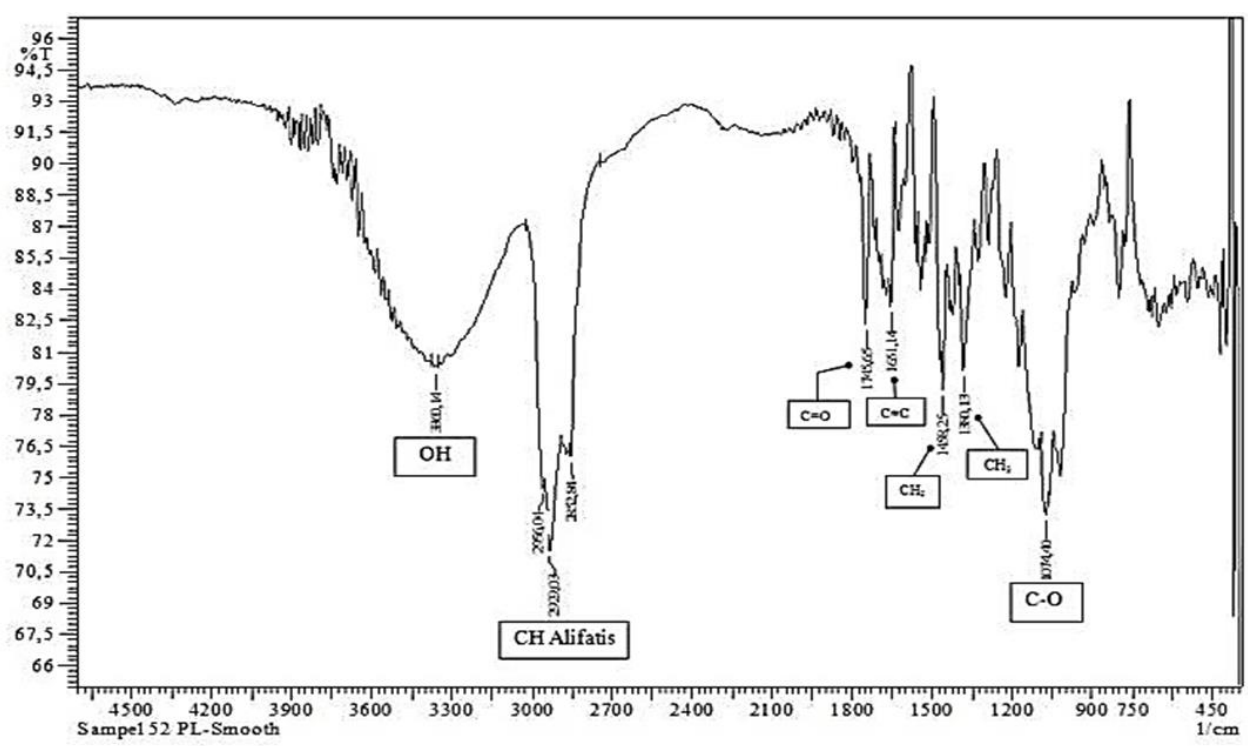

Gambar 3. Spektrum FT-IR Senyawa Isolat CHP1

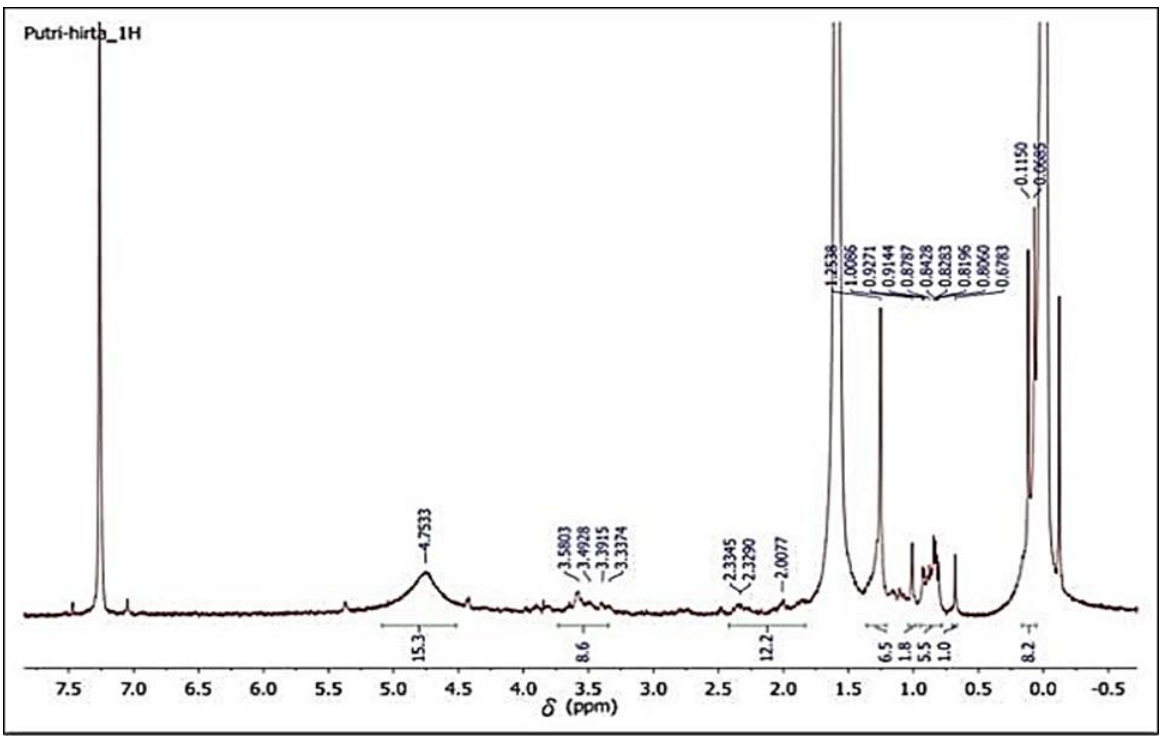

Gambar 4. Spektrum ${ }^{1}$ H NMR senyawa Isolat CHP1

$\mathrm{CH} 3$ ) dimana vibrasi ini mengindikasikan adanya gugus gem dimetil yang khas untuk triterpenoid (Astuti et al. 2017). Adanya bilangan gelombang pada daerah $1074 \mathrm{~cm}^{-1}$ menunjukkan adanya gugus fungsi C-O.

Untuk mengidentifikasi lebih lanjut mengenai struktur senyawa, maka dilakukan pengukuran spektrum 1H-NMR (Gambar 4). Analisis ${ }^{1} \mathrm{H}-\mathrm{NMR}$ dilakukan dengan spektrometer NMR $500 \mathrm{MHz}$ dalam pelarut metanol terdeuterasi $\left(\mathrm{CD}_{3} \mathrm{OD}\right)$ hanya menunjukkan sinyal-sinyal proton alifatik yang merupakan ciri khas dari kebanyakan senyawa terpenoid. Pergeseran kimia pada $\delta_{\mathrm{H}}$ $4.75 \mathrm{ppm}(15 \mathrm{H}, \mathrm{m})$ dihasilkan oleh proton alkena, yang menunjukkan bahwa senyawa tersebut terdapat ikatan $\mathrm{C}=\mathrm{C}$ alkena. Sedangkan pergeseran kimia pada $\delta_{\mathrm{H}} 3.58$ ppm $(9 \mathrm{H}, \mathrm{m})$ menunjukkan tipe proton $\mathrm{CH}_{2} \mathrm{OH}$.

Selanjutnya pada pergeseran kimia $\delta_{\mathrm{H}}$ $2.33 \mathrm{ppm}(12 \mathrm{H}, \mathrm{d}, \mathrm{J}=2,75 \mathrm{~Hz}), \delta_{\mathrm{H}} 1.15 \mathrm{ppm}$ $(7 \mathrm{H}, \mathrm{s}), \delta_{\mathrm{H}} 0.87 \mathrm{ppm}(2 \mathrm{H}, \mathrm{s}), \delta_{\mathrm{H}} 0.84 \mathrm{ppm}(5 \mathrm{H}$, $\mathrm{m}), \delta_{\mathrm{H}} 0.81 \mathrm{ppm}(1 \mathrm{H}, \mathrm{s})$, dan $\delta_{\mathrm{H}} 0.11 \mathrm{ppm}(8 \mathrm{H}$, 
s) dihasilkan oleh proton-proton pada gugus metil dari senyawa terpenoid. Namun, dari hasil ${ }^{1} \mathrm{H}$ NMR tersebut, belum dapat ditentukan bentuk strukturnya karena kurangnya karakterisasi senyawa yang dilakukan.

Tabel 1. Hasil Uji Aktivitas Antioksidan F12, Senyawa CHP1 dan Vitamin C

\begin{tabular}{lll}
\hline \multicolumn{1}{c}{ Sampel } & \multicolumn{1}{c}{$\begin{array}{c}\text { IC50 } \\
(\boldsymbol{\mu g} / \mathbf{m L} \mathbf{m})\end{array}$} & \multicolumn{1}{c}{$\begin{array}{c}\text { Daya } \\
\text { Antioksidan }\end{array}$} \\
\hline F12 & 26,39 & Sangat Kuat \\
Senyawa CHP1 & 327,01 & Lemah \\
Vitamin C & 8,76 & Sangat Kuat \\
\hline
\end{tabular}

Hasil uji aktivitas antioksidan dapat dilihat pada Tabel 1. Hasil pengujian menunjukkan Fraksi 12 memiliki nilai IC $_{50}$ yang paling kecil yang berarti memiliki aktivitas antioksidan sangat kuat yaitu 26,39 $\mu \mathrm{g} / \mathrm{mL}$ sedangkan senyawa CHP1 memiliki aktivitas antioksidan yang lemah dengan nilai $\mathrm{IC}_{50} 327,01 \mu \mathrm{g} / \mathrm{mL}$. Hal ini dapat dapat disebabkan karena senyawa isolat CHP1 merupakan senyawa golongan terpenoid dimana senyawa terpenoid ini tidak bisa dengan mudah memberikan salah satu elektronnya kepada DPPH sehingga ketika salah satu elektronnya diberikan kepada DPPH, maka akan mengakibatkan resonansi yang ada didalam molekul senyawa CHP1 kurang mampu menstabilkan radikal pada senyawa CHP1 tersebut (Yuhernita \& Juniarti, 2011; Mustarichie et al, 2017)

Sedangkan hasil pengujian aktivitas antioksidan vitamin $\mathrm{C}$ diperoleh nilai $\mathrm{IC}_{50}$ sebesar sebesar 8,766 $\mu \mathrm{g} / \mathrm{mL}$. Jika dibandingkan dengan nilai $\mathrm{IC}_{50}$ yang didapatkan dari pengujian aktivitas antioksidan F12, senyawa CHP1 dari buah senduduk bulu dengan vitamin $\mathrm{C}$ menunjukkan bahwa vitamin $\mathrm{C}$ menunjukkan aktivitas antioksidan yang sangat kuat daripada sampel. Nilai IC I0 $_{50}$ dianggap sebagai ukuran yang baik dari efisiensi antioksidan senyawa-senyawa isolat ataupun ekstrak (Yuhernita \& Juniarti, 2011). Menurut Mustarichie et al (2017) suatu senyawa dikatakan sebagai antioksidan sangat kuat apabila nilai $\mathrm{IC}_{50}$ kurang dari $50 \mu \mathrm{g} / \mathrm{mL}$, kuat apabila nilai $\mathrm{IC}_{50}$ antara $50-100 \mu \mathrm{g} / \mathrm{mL}$, sedang apabila nilai $\mathrm{IC}_{50}$ berkisar antara 101$250 \mu \mathrm{g} / \mathrm{mL}$, lemah apabila nilai IC $_{50}$ berkisar antara $250-500 \mu \mathrm{g} / \mathrm{mL}$ dan tidak aktif apabila nilai $\mathrm{IC}_{50}>500$. Semakin kecil nilai $\mathrm{IC}_{50}$ berarti semakin aktif senyawa isolat sebagai senyawa penangkap radikal DPPH atau sebagai antioksidan.

\section{KESIMPULAN}

Berdasarkan penelitian yang telah dilakukan didapatkan senyawa isolat CHP1 sebanyak 10 mg berbentuk kristal, berwarna putih dengan titik leleh $165-167^{\circ} \mathrm{C}$. Berdasarkan identifikasi penampak noda menggunakan pereaksi Liebermann-Bourchard menunjukkan senyawa CHP1 merupakan golongan terpenoid yang diperkuat oleh data spektrum UV, FT- IR dan ${ }^{1} \mathrm{H}$ NMR. Selain itu, hasil uji aktivitas antioksidan menunjukkan bahwa senyawa CHP1 memiliki aktivitas antioksidan dengan kategori lemah yang ditunjukkan oleh nilai $\mathrm{IC}_{50}$ sebesar $327,01 \mu \mathrm{g} / \mathrm{mL}$.

\section{Daftar Pustaka}

Agustina, W., Nurhamidah., Dewi, H. 2017. Skirining Fitokimia Dan Aktivitas Antioksidan Beberapa Fraksi Dari Kulit Batang Jarak (Ricinus Communis L.). Jurnal Pendidikan dan IlmuKimia. 1(2),117-22.

Djauhariya, E., Hernani. 2004. GulmaBerkhasiat Obat. Jakarta, PenebarSwadaya.

Gandjar, G., Rohman A. 2007. KimiaFarmasi Analisis. Yogyakarta, PustakaPelajar.

Hostettmann, K., Hostettmann, M., Marston, A. 1995. Cara Kromatografi Preparatif. Terjemahan Padmawinata K. Bandung, Institut Teknologi Bandung. 
Ergina, S. N dan Indarini, D. 2014. Uji Kualitatif Senyawa Metabolit Sekunder Pada Daun Palado (Agave Angustifolia) yang Diekstraksi Dengan Pelarut Air Dan Etanol. J. Akad. Kim. 3(3),165- 172.

Fadhli, H., Soeharto, A. B. R., \& Windarti, T. (2018). Uji Aktivitas Antioksidan Kulit Buah Pulasan (Nephelium mutabile Blume) dan Bunga Turi Putih (Sesbania grandiflora) dengan Metoda DPPH. Jurnal Katalisator, 3(2), 114-124.

Mustarichie, R., Runadi, D., Ramdhani, D. 2017. The Antioxidant Activity And Phytochemical Screening of Ethanol Extract, Fractions of Water, Ethyl Acetate, and N-Hexane From MistletoeTea (Scurrula atropurpurea BL. dans ). Asian J Pharm Clin Res. 10(2),2-6.

Najiah, M., Wan, N., Nadirah, M. 2011. Methanolic Activities of Selected Weeds on Bacteria Isolated from Macrobrachium rosenbergii Larvae. Thai J Vet Med. 41(4), 535-539.

Narasimham, D., Yeduguri, H.B., Sanith, C., Rahul, R., Meruva, K.., Thummala, C., Joseph M. 2017. Evaluation of in Vitro Anticancer and Antioxidant Activities From Leaf Extracts of Medicinal Plant Clidemia hirta. International Journalof Pharmacy and Pharmaceutical Sciences. 9(4),149-153.

Pardede, A. 2018. Uji Aktivitas Antioksidan Dari Ekstrak Etanol Buah Senduduk Bulu (Clidemia hirta (L.) D. Don) dengan Metode Pemerangkapan DPPH (1,1-diphenyl-2picrylhidrazil). Skripsi. Fakultas Farmasi, Universitas Sumatera Utara

Suhartati, T. 2017. Dasar-dasar Spektrofotometri UV- Vis dan Spektrofotometri massa Untuk Penentuan Struktur Senyawa Organik. Penerbit AURA, BandarLampung.

Tjitraresmi, R.A. 2018. Review, Potensi Tanaman Melastomataceae Sebagai Antioksidan. Farmaka Suplemen. 6(1), 26-28.

Wijaya. D., Putri, P.Y., Raffty, S., Muhammad, R. 2015. Screening Fitokimia Dan Aktivitas Antioksidan Daun Eceng Gondok (Eichhornia Crassipes). Jurnal Kimia Valensi. 1(1),6569.

Yuhernita dan Juniarti. 2014. Analisis Senyawa Metabolit Sekunder Dari Ekstrak Metanol Daun Surian yang Berpotensi Sebagai Antioksidan. Makara Sains. 15 (1), 48-52 